Introduction

Northern Literature: Look Here, Look Again

Maureen Long

AS OUR DELICIOUS-LOOKING COVER SUGGESTS, THIS SPECIAL LITERARY issue of the Northern Review is filled with treats. The first of our literary issues came out in 1993 and the second in 2009. This time the interval is only eight years rather than sixteen, and that reflects the increased pace of literary publishing in Alaska and the Yukon. The 1993 issue appeared on the heels of a popular television show called Northern Exposure, which the then director of northern studies at the University of Alaska Fairbanks (UAF) credited with having doubled graduate applications for her program. This year's issue follows on a decade of reality television shows about the North that bank on familiar clichés of frontier living, wilderness expanse, cold winters, gold mining, the oil business, and end-of-the-road quirkiness. Our authors offer a variety of alternatives to those clichés, fresh ways of looking at the North, realities that aren't trying to show you what you thought you already knew. This is not the North you were expecting.

I use many of the works published in the previous two literary issues in a course I teach at Yukon College on literature of the North. Though I rotate the content, one text I always include is Al Purdy's poem "Country of the Young." Purdy spent the summer of 1965 in 
the Arctic, and in the book he produced from that sojourn, North of Summer: Poems from Baffin Island, he talks about the kind of vision it takes to make art. Purdy describes the Group of Seven artist A. Y. Jackson at the age of eighty-three, halfway up a mountain on Baffin Island, painting a picture that says,

\section{Look here}

You've never seen this country

It's not the way you thought it was

Look again

Later in the poem Purdy suggests you have to "stoop a little / bend over and then look up." It takes effort to really see a place, even more effort to powerfully portray what you're seeing, whether you're a visual artist or a writer. When the subject matter has become familiar through an outpouring of popular-culture representations, the task is even more difficult. It requires a different perspective, whether that's from the telescoping of many years of experience or the kaleidoscope of a fresh encounter. The artists in this issue stoop, bend, twist, swoop, squint, and otherwise contort themselves to provide us with fresh perspectives on things we might have stopped looking at some time ago.

The piece in this issue that sent me back most strongly to Purdy's poem was Nancy Lord's "One Writer, Becoming," a reflection on her life as an Alaskan writer. Lord is the only author who has published in all three of our literary issues, and her reflective essay in this one is a lovely coincidence (if you believe in those sorts of things). Inspired by letters saved for over four decades and returned to her by a fellow writer, Lord contemplates her younger self, an Alaskan newcomer in the early 1970s. Lord writes, "I knew that I wanted a life, not a career, and that this life would be tied to Alaska. I had known that, for me, place came before all else; somehow I would figure out how to live in my chosen place, ..." (11). The essay is a tribute to the influence of great writers, the significance of literary friendships, and the importance of finding one's place in the world.

Many of us who have come to the North as adults will see ourselves in Lord's experiences, but this issue of the Northern Review also contains stories by people who have always been here. In " 22 Miles Home" 
Lulla Johns writes about her home on the Alaska-Yukon border and one autumn day some years ago: "I am nine and determined to hide again from the priest who picks us up every year from our summer camp along the Alaska Highway" (19). Johns's memoir is an important contribution to the Northern Review, coming at a time when Canadians are collectively confronting the legacy of residential schools, but her essay also captures the experience of many Alaska Natives who found themselves simultaneously handed a religion and taken away to school under the "civilizing" influence of Sheldon Jackson and his inheritors. This issue also includes autobiographical pieces by five other Indigenous voices; in "Tails on the Trails," UAF Rasmuson Library oral historian Leslie McCartney weaves the dog stories of Gwich'in elders together into a pattern that both deepens and complicates what we thought we knew.

Even older and wilder animals are represented in this collection, including extinct Beringian species viewed from a Whitehorse coffee shop. Some of the animals are stuffed and mounted, others are stuffed and served on the dinner table. A pack of talking coyotes stalks a university campus in what might be the last dark days of civilization. A middle-aged man gets his elk, but he hits it with his truck on the way to his son's graduation. While unmistakably northern, these creatures are definitely not the "Big Five" charismatic megafauna that tourists flock to Denali or Kluane national parks to view.

While I'm giving you teasers ... this issue has two coming-ofage stories, one that plays out in an Alaskan mining town during the Spanish flu epidemic early in the twentieth century, and one that takes place within a Thai community north of the seventy-fourth parallel, in Svalbard, Norway. The poems take us from the formal sound play of a pantoum about plankton to the crack of a bat in beer-league baseball. We meditate on birds, barrens, and barium swallows, and witness a miracle on the Whitehorse trolley.

Where does all this great writing come from, you ask? Partly from the residential creative writing program at the University of Alaska Fairbanks and the low-residency program at the University of Alaska Anchorage, as well as three decades of creative writing courses at Yukon College. Partly from the classes, workshops, fellowships, and peer support of 49 Writers, Yukon Writers' Collective Ink, Kicksled Readings, the Alaska Humanities Forum and Alaska State Council 
on the Arts, the Yukon Department of Tourism and Culture, the Fairbanks Arts Association, and other governmental and non-profit groups. Partly-dare I say it?-from the opportunities afforded by the internet and advances in self-publishing to writers in places far from the metropole. And partly, of course, from you, the readers of good northern writing who provide a relatively small but still crucial audience for those willing to risk discovering hard truths about a place that is so easily filtered through popular myths, recycled plots, and endless hours of reality television.

If you pay attention you might spot Lara Melnik's (our cover artist's) masterpieces all over the Yukon: in a coffee shop or a friend's foyer, a bead on a colleague's necklace, or even on ski trails and in snowy schoolyards in the form of that uniquely northern ornament, the parka pull. Once you start seeing them, you can't help looking at the world in a new way. Our hope is that the poems, essays, and stories in this issue will help you "Look here... / Look again" at some aspects of life in the North, and that maybe you won't ever be able to see it quite the same way again.

\section{Acknowledgements}

I would like to thank my three sparkling co-editors-compatriots Jamella Hagen and Andrew Richardson at Yukon College, and colleague and friend, Eric Heyne of the University of Alaska Fairbanks. Working with these three truly has been a treat. Significantly, Eric is the one other individual who has been involved in all three literary issues, and his dedication to northern literature in all its forms is a continual inspiration. As well, his contributions to and polishing of this introduction cannot be overstated. Finally, thank you to managing editor, Deanna McLeod, for her boundless energy, expertise, enthusiasm, and good humour.

\section{Guest Editor}

Maureen Long is an English instructor at Yukon College. 